\title{
INTRODUCTION TO THE PUBLICATION OF KNUT WICKSELL'S LECTURES ON THE ECONOMIC CONSEQUENCES OF THE FIRST WORLD WAR (1919)
}

In our preparations for the Arne Ryde Symposium on the Theoretical Contributions of Knut Wicksell, we made a search for interesting works of Wicksell which had not previously been published or translated into English. In spite of the very large amount of printed notes, articles and books by Knut Wicksell-the bibliography by E. J. Knudtzon and T. Hedlund-Nyström Knut Wicksells tryckta skrifter 1868-1950 (The Publications of Knut Wicksell, 18681950) ${ }^{1.2}$ contains more than 800 items-the archives at the Lund University Library were found to hide many largely unknown, handwritten manuscripts of Wicksell, mostly fairly complete notes to courses or lectures. The mimeographed publication which we presented at the symposium ${ }^{2}$ contains Wicksell's notes to his lectures in Uppsala in 1919 on "The World War: An Economist's View" (Världskriget ur ekonomisk synpunkt), and his notes to a series of lectures in Stockholm in 1889, "On Value, Capital and Interest according to Modern Economic Theories". We also included a translated version of the first chapter of the first edition (1901) of Wicksell's "Lectures on Political Economy", which for some particular reason had never been translated into English.

Wicksell's lecture notes on the economic consequences of the First World War are published in this special issue of The Scandinavian Journal of Economics, along with a foreword by Bengt Reuterskiöld and Michael D. Bordo, who edited and translated Wicksell's notes. This series of lectures is remarkable in several respects. In this popular exposition, it is impressive to observe the natural ease and pedagogical efficiency with which Wicksell uses his (and Böhm-Bawerk's) theoretical concept of capital as stored-up labor and land services to explain the tremendous outburst of productive power during the war years and the great difficulties of restoring capitalistic production to a prewar level after 1918. Of course it is also very interesting to follow the thorough and varied argumentation of this old Malthusian thinker on the significance of the changes caused by the war in the size and structure of the population; and to read his quite optimistic considerations on the prospects for the League of Nations.

Lund, November, 1977

Björn Thalberg

${ }^{1}$ Lund, 1976.

- Available on request from the Institute of Economics, Fack, S-220 05 Lund, Sweden. 